\title{
Nociceptors and warm receptors innervated by C fibres in human skin
}

\author{
ROLF G HALLIN,* H ERIK TOREBJÖRK, $† Z$ WIESENFELD* \\ From the Department of Clinical Neurophysiology, Huddinge University Hospital,* Huddinge, and the \\ Department of Clinical Neurophysiology, University Hospital, $\uparrow$ Uppsala, Sweden
}

SUMMARY The properties of $125 \mathrm{C}$ fibre units recorded from the peripheral nerves of conscious man were studied. On the basis of receptive field properties and responses to natural stimulation, 120 of the units were classified as polymodal $\mathrm{C}$ nociceptors. Five of the units were identified as specific $\mathrm{C}$ warm receptors. In contrast to the polymodal nociceptors, which often had comparatively large and complex receptive fields with several receptive maxima, receptive fields of the thermoreceptors consisted of one single spot. Polymodal nociceptors responded readily to moderately intense and noxious mechanical stimuli whereas the warm receptors produced inconsistent responses to even intense mechanical skin stimulation. Thermal stimulation in the innocuous range, perceived as warmth, optimally excited the thermoreceptors whereas the polymodal $\mathrm{C}$ nociceptors fired most intensely to noxious painful heat.

Microelectrodes percutaneously inserted into intact human skin nerves permit recording of neural signals deriving from the full nerve fibre size spectrum. ${ }^{1-3}$ Even single unit activity in unmyelinated $\mathrm{C}$ fibres has been identified. ${ }^{4-6}$ Afferent and efferent sympathetic $\mathrm{C}$ units can be differentiated ${ }^{4}$ and their properties have been described in some detail.4 6-8 Two types of afferent $C$ units have been distinguished to date. The properties of polymodal $\mathrm{C}$ nociceptors have been investigated in several studies. ${ }^{6-13}$ Only a few reports have been published about $\mathrm{C}$ warm receptors, ${ }^{12} 1415$ the other C-receptor type identified in man.

Particular emphasis was focused in this study on comparing the characteristics of polymodal $\mathrm{C}$ nociceptors with those of specific $\mathrm{C}$ warm receptors. Preliminary reports of the present results have been presented elsewhere. ${ }^{12} 13$

\section{Methods}

Tungsten microelectrodes ${ }^{16}$ percutaneously inserted into human skin nerves in situ were used to record afferent C fibre activity from 15 conscious subjects aged 30-40

Address for reprint requests: Dr Rolf G Hallin, Department of Clinical Neurophysiology, Huddinge University Hospital, S-141 86 Huddinge, Sweden.

Received 5 July 1981. Accepted 27 August 1981 years. They had no symptoms of any dermatological or neurological disease. Descriptions of the electrodes, the experimental procedure and the recording, display and analysis systems have been presented in detail previously. ${ }^{2} 617$

\section{Material}

Unitary C fibre signals were recorded from the radial, peroneal or saphenous nerves. Of a total of 125 afferent $\mathrm{C}$ units studied, 42 single units could be identified by the amplitude and waveform of the action potential in the original neurogram, whereas the rest of the units were classified by a combination of electrical test shocks and physiological stimuli, as shown in figs 1 and 4 (cf ref $7,11,18$ ). Briefly, suprathreshold $0 \cdot 2-0 \cdot 3 \mathrm{~Hz}$ electrical shocks were delivered in the cutaneous receptive field of $\mathrm{C}$ afferents. The spikes were discriminated with a Schmitt trigger and the responses to successive stimuli were displayed as a dot raster. Mechanical or thermal stimuli were applied occasionally during the repetitive electrical stimulation. The response of a unit to the natural stimuli could be observed as an increase in latency of the $\mathrm{C}$ unit to electrical stimulation in the raster display, owing to the decrease in conduction velocity of the $\mathrm{C}$ unit as a result of activation by the mechanical or thermal stimuli. Thermal stimuli were occasionally observed to cause an increase in conduction velocity (fig 1) presumably due to warming of the afferent fibre. ${ }^{19}$ One hundred and twenty of the units could be classified as polymodal $\mathrm{C}$ nociceptors and five as specific $\mathrm{C}$ warm receptors.

The receptive characteristics of the $C$ units were tested first with weak stimuli and then successively stronger 


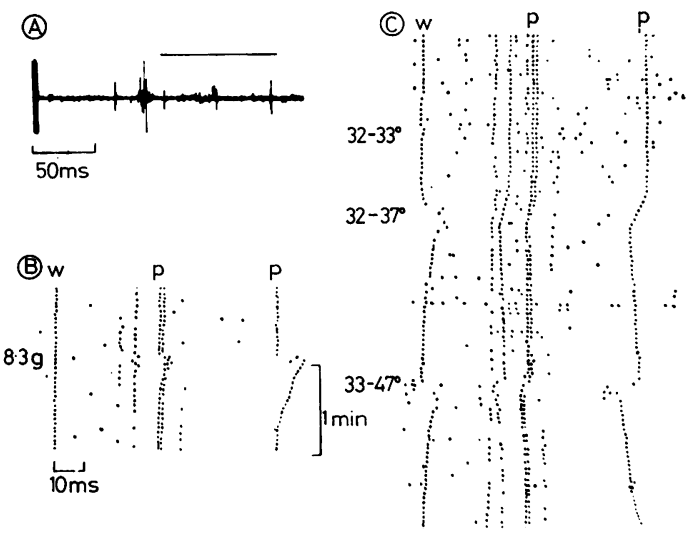

Fig 1 Differentiation between polymodal nociceptors and a warm receptor supplied by C fibres. Recording from radial nerve at wrist level. Conduction distance $7.5 \mathrm{~cm}$. (A) Electrical stimulation at $0.3 \mathrm{~Hz}$ in the receptive field induced activity in a large number of nonmyelinated afferents. The dot rasters in $B$ and $C$ show successive responses of the later part of the response (bar). The earlier multiunit cluster, which was composed of responses of polymodal nociceptors, were not included in this raster display. (B) Pressure with a von Frey hair $(8.3 \mathrm{gm})$ evoked activity in the polymodal $(p)$ units but not the warm $(w)$ unit. $(C)$ Slight increase in skin temperature $\left(32-33^{\circ} \mathrm{C}\right)$ mildly excited the $w$ unit but not the $p$ units. Moderate increase in temperature $\left(32-37^{\circ} \mathrm{C}\right)$ perceived as warmth, activated the $w$ unit, but only caused a decrease in the conduction velocity of the $p$ units (see text). A strong increase in temperature $\left(33-47^{\circ} \mathrm{C}\right)$ perceived as painfully hot, excited both $w$ and $p$ units, especially the last $p$ unit.

mechanical or thermal stimuli. The application of each stimulus was usually followed by a pause of about 2 min in order to avoid depressing the excitability of the receptive endings. ${ }^{62}$ The subjects were instructed to report the sensations experienced by choosing among a small number of descriptions for the sensations felt. The perceptions felt were thus reported as being of, for example, a throbbing, tapping, pricking or painful character. They were generally prevented from listening to the neural activity over the loudspeaker, seeing the spikes on the oscilloscope screen or seeing the test procedures performed.

\section{Stimulation procedures}

Mechanical stimuli Mapping of receptive fields and testing of stimulus response characteristics to graded mechanical stimuli were performed manually with calibrated von Frey's hairs.

Thermal stimuli The skin was warmed with an electrically heated thermode with an aluminium tip (tip diameter $2.0 \mathrm{~mm}$ ) similar to that previously used in animal studies. ${ }^{20}$ A thermistor and feed-back circuit buried in the probe? it possible to stimulate the skin at predetermined temperatures. The temperature of the probe could be increased by $5^{\circ} \mathrm{C}$ in about $3 \mathrm{~s}$ within the range of $30-60^{\circ} \mathrm{C}$. A DC voltage corresponding to the temperature of the stimulator was recorded simultaneously with neural activity. The thermode was held on the skin with a manipulator. No activity in the studied $C$ fibre receptors was induced by the gentle pressure exerted by the probe itself.

Electrical stimuli Electrical stimulation of the skin at $0 \cdot 2-1 \mathrm{~Hz}$ was performed using a Grass $\mathrm{S} 48$ stimulator (with a Grass SIU 5 stimulus isolation unit). The stimuli were applied through thin uninsulated steel needles, diameter $0.3 \mathrm{~mm}$, inserted intradermally about $2-3 \mathrm{~mm}$ apart within the innervation zone of the impaled skin nerve fascicle. The conduction velocities of the nerve fibres were calculated by determining the latencies of the $\mathrm{C}$ units at the recording electrode and measuring the distance between the stimulating and recording sites.

\section{Results}

CHARACTERISTICS OF POLYMODAL NOCICEPTORS WITH C FIBRES

\section{Identification and general discharge characteristics}

In agreement with the characteristics of $\mathrm{C}$ nociceptors previously identified in man, ${ }^{6911} 21$ the 42 units studied in the original neurogram were not active at normal skin temperature of around $35^{\circ} \mathrm{C}$ in the absence of intentional stimulation. Gentle mechanical stimuli such as bending hairs or touching the skin with cotton wool did not excite the $\mathrm{C}$ units. Nonpainful pressure or stimulation with coarse von Frey's hairs induced sparse activity in the $\mathrm{C}$ nociceptors and sometimes evoked sensations of pricking or slightly painful itch. The distribution of mechanical thresholds as obtained with von Frey's hair testing ranged from $0.7 \mathrm{~g}$ to $13 \mathrm{~g}$. Typically the units were best activated by intense stimuli, such as needle pricks or heating the skin to painful intensities within the receptive field, stimuli which threatened to disrupt the integrity of the skin.

The responses of 78 nociceptor endings obtained from 22 multifibre recordings could be analysed using the technique of a dot raster display. In the display shown in fig 1B four C nociceptors, " $p$ ", showed marked slowing of their conduction velocities when testing the skin with a von Frey's hair exerting a force of $8.3 \mathrm{~g}$. Since the units all exhibited latency increases simultaneously when performing various tests at different sites in the skin, it was concluded that these $\mathrm{C}$ nociceptors had overlapping receptive fields. By contrast, the specific warm unit " $w$ " did not respond with latency changes following mechanical skin stimulation but displayed slowing in conduction velocity after an increase of 
skin temperature within the receptive field (fig 1C).

\section{C fibre responses to thermal stimuli}

Thirty of the polymodal $\mathrm{C}$ nociceptors reliably identified in the original neurogram were tested with well controlled temperature stimuli of up to $30 \mathrm{~s}$ duration, ranging from non-noxious to clearly noxious levels $\left(38-52^{\circ} \mathrm{C}\right)$. Fifteen of these elements could be studied long enough for repeated testing of the units at a variety of skin temperatures. Figure 2A illustrates the firing frequencies at

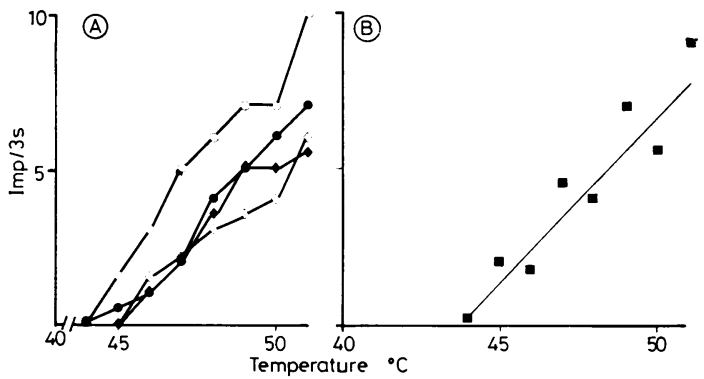

Fig 2 (A) The response of four single polymodal $C$ units to stimulation at various temperatures. The total number of impulses in the first $3 \mathrm{~s}$ after the application of the stimulation are shown. Stimulus periods were separated by about two minutes in order to avoid receptor fatigue. (B) The average response for $3 s$ of 15 polymodal $C$ nociceptors.

different stimulus temperatures for four of these polymodal $\mathrm{C}$ units, whereas fig $2 \mathrm{~B}$ illustrates the average responses of all 15 units. The responses of the units were analysed and the first $3 \mathrm{~s}$ of stimulation were compared since the units generally respond most vigorously during this period (cf 22). The threshold temperature during the first trial for inducing single spikes at a low firing frequency in these and other $\mathrm{C}$ nociceptors (fig $2 \mathrm{~B}$ ) was between 44 and $46^{\circ} \mathrm{C}$. These temperatures generally were perceived as slightly painful. The average frequency of firing increased slightly after raising the stimulus temperature, but even with clearly noxious stimuli of $50-52^{\circ} \mathrm{C}$ the mean frequency of firing seldom exceeded $3 \mathrm{imp} / \mathrm{s}$. With stimuli of this magnitude a distinct intense pain was felt. At the highest temperatures tested the units fired at about $4 \mathrm{imp} / \mathrm{s}$ and elicited bursts of impulses with interspike intervals of $40-115 \mathrm{imp} / \mathrm{s} .{ }^{11}$

\section{Organisation of receptive fields}

The receptive skin area of the $\mathrm{C}$ nociceptors extended from about $1 \mathrm{~mm}^{2}$ to up to more than $1 \mathrm{~cm}^{2}$. The receptive fields were often complex with several point-like receptive maxima separated by areas where the units were relatively nonresponsive. The most complex and largest receptive fields were often found distally in the skin of the leg, whereas only a few receptive spots generally were encountered in $\mathrm{C}$ units with receptive fields on the dorsum of the hand. Figure 3 illustrates that the threshold

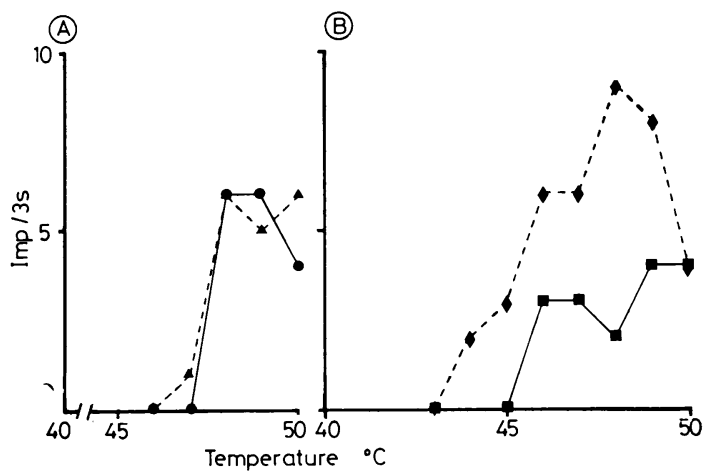

Fig 3 Responses of two polymodal $C$ nociceptive units $(A$ and $B)$ to a variety of temperature stimuli. In $A$ are shown the responses to stimulation of two receptive maxima within the receptive field for one unit, in $B$ are the equivalent responses for the other unit. The ordinate represents the total number of impulses in the first $3 \mathrm{~s}$ after application of the stimulator. (A) Similar threshold and response magnitudes to stimulation of the two receptive maxima are seen. $(B)$ Different threshold and response magnitudes to stimulation of the two receptive maxima are apparent.

temperature in the $\mathrm{C}$ units varied among the receptive spots. In some $\mathrm{C}$ units the discharges that could be evoked from the different receptive maxima with increasing temperature were similar (fig 3A). In other units there was a variable temperature sensitivity of different maxima with varying responses evoked by the same thermal stimuli (fig 3B). Repetitive stimulation at noxious skin temperatures eventually resulted in decreased firing of the tested nociceptive $\mathrm{C}$ afferent terminal. This was probably the reason why the vigorously responding $\mathrm{C}$ ending in fig 3B fired more intensely at a stimulus temperature of $49^{\circ} \mathrm{C}$ than at $50^{\circ} \mathrm{C}$.

\section{CHARACTERISTICS OF SPECIFIC WARM}

RECEPTORS WITH C FIBRES

To date only five units have been reliably identified as specific $\mathrm{C}$ warm receptors. Two units were studied in detail with regard to their response to a large range of temperatures (figs 1,6 ). The receptive area of all five $\mathrm{C}$ warm receptors was one small spot (fig 4A). This same unit was not consistently excited by relatively intense mechanical skin stimuli of up 


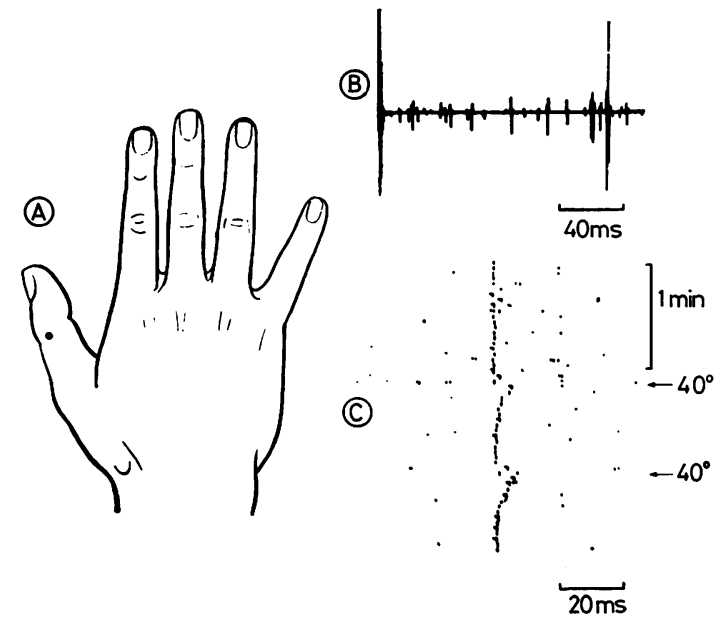

Fig 4 (A) The receptive field of a warm unit recorded from the radial nerve. The field consisted of a single sensitive spot. $(B)$ The response evoked by intradermal electrical stimulation at $0 \cdot 3 \mathrm{~Hz}$ in the region of the skin receptive field. The large action potential is the well isolated warm unit. $(C)$ Dot raster display of the response of the unit to warming the skin receptive field from $33^{\circ}$ to $40^{\circ} \mathrm{C}$ combined with electrical stimulation near the receptor. The first $150 \mathrm{~ms}$ are not shown. The thermal stimulus was perceived as warmth, but not heat, and evoked responses in the unit as indicated by the increased latency. to $8.5 \mathrm{~g}$ (fig $5 \mathrm{~A}$, left) whereas small increases in stimulus temperature of the order of $1^{\circ} \mathrm{C}$ were sufficient to excite it (fig 5B). From these observations it was concluded that this particular unit was a specific warm receptor. Steady state responses up to $3 \mathrm{imp} / \mathrm{s}$ did not evoke any conscious sensation when

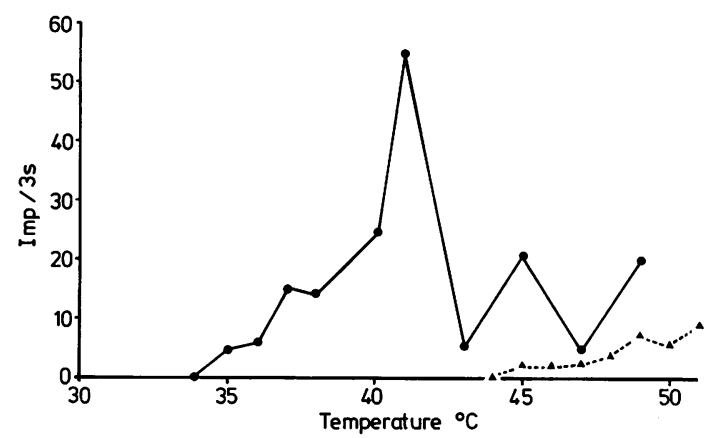

Fig 6 Total number of spikes for a warm unit during the first $3 \mathrm{~s}$ after the application of thermal stimuli (filled circles) in comparison with the averaged total impulse number during corresponding periods for 15 polymodal $C$ nociceptive units (triangles).

stimulus temperature was lower than $40^{\circ} \mathrm{C}$. When increasing the stimulus from $39^{\circ} \mathrm{C}$ to $40^{\circ} \mathrm{C}$, however, the subject reported a sensation of warmth (fig 5B). Further increase of the stimulus temperature induced

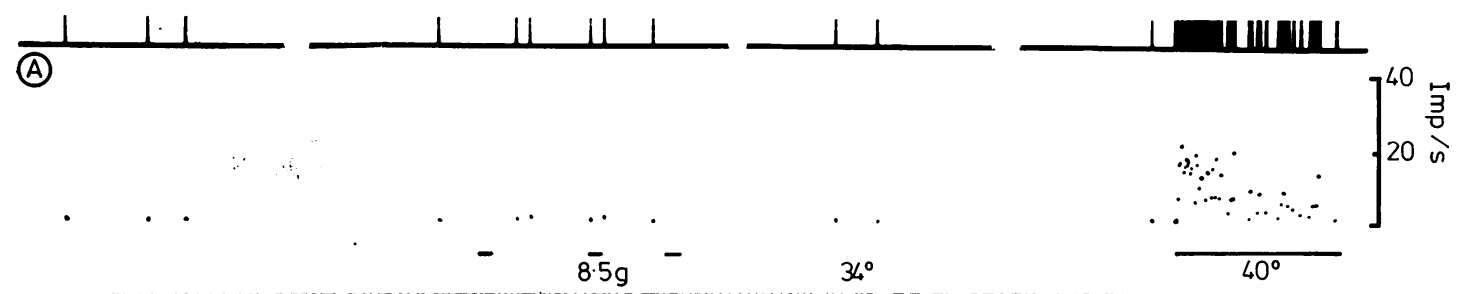

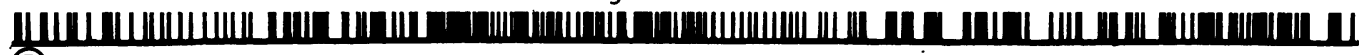
(B)

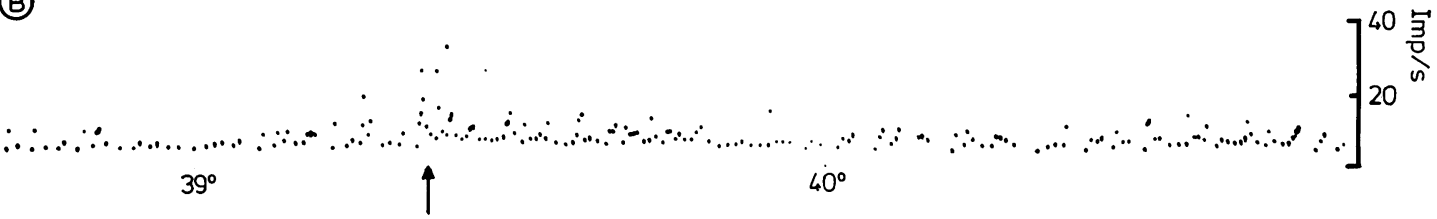

Fig 5 The response of a warm unit to mechanical and thermal stimuli. The action potentials were converted to standard pulses. The instantaneous firing frequency is presented underneath the pulse trace. The type and duration of the applied stimuli are also indicated. Same time base in $A$ and $B$. Trace B represents continuous activity for $90 s$. $(A)$ In the absence of any skin stimulation there sometimes was sparse unitary activity (left). Mechanical stimuli of $8 \cdot 5 \mathrm{~g}$ evoked no consistent response. At a skin temperature of $34^{\circ} \mathrm{C}$ the unit was almost silent. A vigorous response was evoked by suddenly warming the skin to $40^{\circ} \mathrm{C}$. This was perceived as warmth by the subject. (B) At a constant skin temperature of $39^{\circ} \mathrm{C}$ the unit discharged at about $5 \mathrm{imp} / \mathrm{s}$ and was not perceived by the subject. A slight warming to $40^{\circ} \mathrm{C}$ evoked a transient increase in firing frequency and was perceived as warmth (arrow). After about $3 \mathrm{~s}$ the previous level of firing was resumed. 
static firing at a higher frequency with a peak discharge of about $55 \mathrm{imp} / 3 \mathrm{~s}$ at a temperature of $41^{\circ} \mathrm{C}$ (fig 6).

The qualitative aspects of a $\mathrm{C}$ warm receptor described above were studied in three additional units using the raster display technique. In contrast to the nociceptive $\mathrm{C}$ afferents which were excited by moderately intense mechanical stimuli, the $\mathrm{C}$ warm receptors were not excited by such stimulation. Slight warming of the skin, however, produced a slight latency increase for $\mathrm{C}$ warm units in the raster display (fig 1C, top, fig 4C). Typically, greater magnitudes of the applied temperature rise induced more pronounced latency increases. Polymodal C nociceptive units studied simultaneously showed a decrease in latency due to an increase in conduction velocity in the peripheral nerve fibre twigs by the mild heating (fig 1C). Only during intensely painful heating of the skin $\left(33-47^{\circ} \mathrm{C}\right)$ did the heat-induced firing in the $\mathrm{C}$ nociceptors induce a latency increase of the units which partly counteracted the latency decrease evoked by the heating itself.

\section{Discussion}

CHARACTERISTICS OF SKIN RECEPTORS

SUPPLIED BY C FIBRES IN MAN

In this investigation some characteristics of two main types of $\mathrm{C}$ fibre receptors in man are reported. The majority of the identified units derived from end organs which were excited by a variety of moderately intense and noxious mechanical, thermal and chemical stimuli in the skin. Even if our sampling technique in part may have been biased it seems safe to conclude that another much smaller group of $\mathrm{C}$ receptors responded specifically to thermal stimuli and most vigorously to innocuous warming, whereas any type or intensity of mechanical stimulation gave inconsistent responses (figs 1,5 ).

The distinction between the two groups of $\mathrm{C}$ fibre elements was quite apparent. Receptors supplied by "nociceptive" fibres had comparatively large receptive fields often comprised of several point-like receptive maxima spread out in the skin. Stimulation of individual receptive maxima could evoke similar or quite different responses (fig 3). Skin regions between the maxima were much less sensitive to stimulation. In addition these units had no ongoing activity in the absence of intentional stimulation. They responded most intensely to noxious mechanical or thermal stimuli and enhanced responsiveness of some of these $\mathrm{C}$ units could be demonstrated following repeated testing with noxious heat. ${ }^{13}$ The properties of the units were in good general agreement with those of polymodal nociceptors and their namesakes previously described in cat ${ }^{23-25}$ and monkey ${ }^{2026-28}$ and the same as for those previously called polymodal $C$ nociceptors in man. 91121

By contrast the receptive field of the thermosensitive units consisted of only one small spot (fig 4). These units exhibited an ongoing activity and responded vigorously to innocous warming, whereas mechanical stimuli of even relatively high intensity were ineffective. In all respects the characteristics of these units were reminiscent of those ascribed to specific warm receptors described in animals ${ }^{29-32}$ and man. ${ }^{12} 14$

The majority of the sensory units with $\mathrm{C}$ fibres in monkey cutaneous nerves conformed to the type of receptor described as polymodal nociceptor whereas the occurrence of specific $\mathrm{C}$ warm receptors was rare. ${ }^{28} 33$ These observations accorded well with our results and other data acquired on $\mathrm{C}$ fibre receptors in man to date ${ }^{11}$ which also suggest that the majority of the afferent unmyelinated fibres in the skin innervate polymodal $\mathbf{C}$ nociceptors. Low-threshold $\mathrm{C}$ mechanoreceptors which are abundant in the cat ${ }^{34}$ are relatively sparse in distal limb nerves of the monkey ${ }^{33}$ and have hitherto not been identified in man. This negative finding may suggest that lowthreshold $\mathrm{C}$ mechanoreceptors are few or absent in man but could also be due to a biased sampling or testing technique or both. ${ }^{11}{ }^{21}$ Additional studies on human $\mathrm{C}$ fibre units are necessary to elucidate still unanswered questions concerning the occurrence, regional distribution and detailed characteristics of $\mathrm{C}$ fibre receptors and their role in sensation in man.

IMPULSES IN POLYMODAL C NOCICEPTORS, SPECIFIC WARM RECEPTORS WITH C FIBRES AND PERCEPTION

The present data and results from other studies 36911 showed that the most vigorous responses in polymodal $\mathrm{C}$ nociceptors were induced by noxious mechanical or thermal stimuli which were felt as intensely painful. The findings that enhanced reactivity of heat-sensitised $\mathrm{C}$ nociceptors was associated with hyperalgesia ${ }^{13}$ and that blocking of $\mathrm{C}$ nociceptor responses by a topical anaesthetic reduced the perception of noxious skin pain ${ }^{35}$ lend further support to the idea that activity in polymodal $\mathrm{C}$ nociceptors is accompanied by pain. It should be recalled, however, that the bulk of evidence suggests that also other elements within the sensory spectrum are important for pain perception. ${ }^{29}$ 36-38

Stimuli which excite $\mathrm{C}$ nociceptors will usually also evoke impulses in thick and thin myelinated fibres. The fact that a few impulses in $\mathrm{C}$ nociceptors induced by electrical or mechanical stimuli may be perceived as nonpainful 61121 could be due to simultaneous activation of $A \alpha \beta$ fibres. Sometimes low frequency activity in the polymodal $\mathrm{C}$ nociceptors was corre- 
lated with a slightly itching pain sensation suggesting that $\mathbf{C}$ nociceptors may contribute also to the sensation of itch. ${ }^{11} 13$

A number of investigations where data from studies on animals were combined with psychophysical experiments in man suggested that the nerve signals perceived as warmth were mediated via C fibres. ${ }^{28}$ These previous results accorded well with evidence from preferential nerve blocks in $\operatorname{man}^{3}{ }^{39}$ indicating that not only pain but also warmth and heat are transmitted through $\mathrm{C}$ fibres. The present and other observations on human warm receptors ${ }^{121415}$ demonstrated that these afferents fired optimally at innocuous skin temperatures felt as warmth. Together, present data obtained in mammals on specific $\mathbf{C}$ warm receptors firmly establish their role as mediators for the sensation of warmth in man. The sensation of heat, which starts at around $45^{\circ} \mathrm{C}$, probably involves activation of both $\mathrm{C}$ warm receptors and polymodal nociceptors. The latter start discharging at around $45^{\circ} \mathrm{C}$. At higher temperatures which are perceived as painfully hot, the warm receptors are inactive (fig 6) and primarily the nociceptors respond. It has previously been shown that nociceptors may have extensively overlapping receptive fields and even a small pointed stimulus can activate several receptors. ${ }^{7}$ Although we have no information about the innervation density of polymodal nociceptors in human skin it is tempting to assume that the conscious perception of heat pain would result from summated activity in many nociceptors and warm receptors. ${ }^{40}$

This work was supported by Swedish Medical Research Council Grant No K79-14V-5318-02, B81-14X-05960-01, Harald Jeanssons Stiftelse, Harald och Greta Jeanssons Stiftelse and research funds of the Karolinska Institute. The thermostimulator was kindly supplied by Professor E Perl, University of North Carolina.

\section{References}

${ }^{1}$ Hallin RG, Torebjörk HE. C-fibre components in electrically evoked compound potentials recorded from human median nerve fascicles in situ. Acta Soc Med Upsalien 1970;75:77-80.

${ }^{2}$ Hallin RG, Torebjörk HE. Electrically induced A and C fibre responses in intact human skin nerves. Exp Brain Res 1973;16:309-20.

3 Torebjörk HE, Hallin RG. Perceptual changes accompanying controlled preferential blocking of $\mathrm{A}$ and $\mathrm{C}$ fibre responses in intact human skin nerves. Exp Brain Res 1973;16:321-32.

${ }^{4}$ Hallin RG, Torebjörk HE. Afferent and efferent C units recorded from human skin nerves in situ. Acta Soc Med Upsalien 1970;75:277-81.
5 Torebjörk HE, Hallin RG. C fibre units recorded from human sensory nerve fascicles in situ. Acta Soc Med Upsalien 1970;75:81-4.

${ }^{6}$ Torebjörk HE, Hallin RG. Identification of afferent C units in intact human skin nerves. Brain Res 1974; 67:387-403.

${ }^{7}$ Hallin RG, Torebjörk HE. Methods to differentiate electrically induced afferent and sympathetic $\mathrm{C}$ unit responses in human cutaneous nerves. Acta Physiol Scand 1974;92:318-31.

${ }^{8}$ Hallin RG, Torebjörk HE. Single unit sympathetic activity in human skin nerves during rest and various manoeuvres. Acta Physiol Scand 1974;92: 303-17.

${ }^{9}$ Gybels J, Handwerker HO, Van Hees J. A comparison between the discharges of human nociceptive nerve fibres and the subject's ratings of his sensations. $J$ Physiol (London) 1979;292:193-206.

${ }^{10}$ Hallin RG, Torebjörk HE. Activity in unmyelinated nerve fibres in man. In: Bonica JJ, ed. Advances in Neurology, Vol. 4. New York: Raven, 1974:19-27.

11 Torebjörk HE. Afferent $\mathrm{C}$ units responding to mechanical thermal and chemical stimuli in human nonglabrous skin. Acta Physiol Scand 1974;92:374-90.

12 Torebjörk HE, Hallin RG. Skin receptors supplied by unmyelinated (C) fibres in man. In: Zotterman Y, ed. Sensory Functions of the Skin in Primates. Oxford: Pergamon, 1976:475-85.

13 Torebjörk HE, Hallin RG. Microneurographic studies of peripheral pain mechanisms in man. In: Bonica JJ, Liebeskind JC, Albe-Fessard DG, eds. Advances in Pain Research and Therapy, Vol. 3. New York: Raven, 1974:121-31.

${ }^{14}$ Konietzny F, Hensel $\mathrm{H}$. Warm fiber activity in human skin nerves. Pflügers Arch 1975;359:265-7.

${ }^{15}$ Konietzny $F$, Hensel $H$. The dynamic response of warm units in human skin nerves. Pflügers Arch 1977;370:111-4.

${ }^{16}$ Vallbo Å, Hagbarth KE. Activity from skin mechanoreceptors recorded percutaneously in awake human subjects. Exp Neurol 1968;21:270-89.

17 Hagbarth KE, Hongell A, Hallin RG, Torebjörk HE. Afferent impulses in median nerve fascicles evoked by tactile stimuli of the human hand. Brain Res 1970;24:423-42.

18 Torebjörk HE, Hallin RG. Responses in human A and C fibres to repeated electrical intradermal stimulation. J Neurol Neurosurg Psychiatry 1974;37: 653-64.

${ }^{19}$ Paintal AS. Conduction properties of normal peripheral mammalian axons. In: Waxman SG, ed. Physiology and Pathobiology of Axons. New York: Raven, 1978:131-44.

${ }^{20}$ Bessou P, Perl ER. Response of cutaneous sensory units with unmyelinated fibers to noxious stimuli. $J$ Neurophysiol 1969;32:1025-43.

21 Van Hees J, Gybels JM. Pain related to single afferent C fibres from human skin. Brain Res 1972;48: 397-400.

22 Beitel RE, Dubner R. Response of unmyelinated (C) polymodal nociceptors to thermal stimuli applied to monkey's face. J Neurophysiol 1976;39:1160-75. 
${ }^{23}$ Iggo A. Cutaneous heat and cold receptors with slowly conducting (C) afferent fibres. Quart $J$ Exp Physiol 1952;44:362-70.

${ }^{24}$ Iggo A. Cutaneous mechanoreceptors with afferent $\mathrm{C}$ fibres. J Physiol (London) 1960;152:337-53.

${ }^{25}$ Witt I. Aktivität einzelner C-Fasern bei schmerzhaften und nicht schmerzhaften Hautreizen. Acta Neuroveg (Wien) 1962;24:208-19.

${ }^{26}$ Bessou P, Burgess PR, Perl ER, Taylor CB: Dynamic properties of mechanoreceptors with unmyelinated (C) fibres. $J$ Neurophysiol $1971 ; 34: 116-31$.

${ }^{27}$ Georgopoulus AP. Functional properties of primary afferent units probably related to pain mechanisms in primate glabrous skin. $J$ Neurophysiol 1976;39: 71-83.

${ }^{28} \mathrm{La}$ Motte RH, Campbell JN. Comparison of responses of warm and nociceptive C-fiber afferents in monkey with human judgements of thermal pain. $J$ Neurophysiol 1978;41:509-28.

${ }^{29}$ Burgess PR, Perl ER. Cutaneous mechanoreceptors and nociceptors. In: Iggo A, ed. Handbook of Sensory Physiology, Vol. 2. Berlin: Springer, 1973: 29-78.

${ }^{30}$ Hensel H, Iggo A. Analysis of cutaneous warm and cold fibers in primates. Pflügers Arch 1971;329:1-8.

${ }^{31}$ Hensel H, Iggo A, Witt I. A quantitative study of sensitive cutaneous thermoreceptors with $\mathrm{C}$ afferent fibres. J Physiol (London) 1960;153:113-26.

32 Iggo A. Cutaneous thermoreceptors in primates and subprimates. J Physiol (London) 1969;200:403-30.

${ }^{33}$ Kumasawa T, Perl ER. Primate cutaneous sensory units with unmyelinated (C) afferent fibres. $J$ Neurophysiol 1977;40:1325-37.

${ }^{34}$ Douglas WW, Ritchie JM, Straub RW. The role of non-myelinated fibres in signalling cooling of the skin. J Physiol (London) 1960;150:266-83.

${ }^{35}$ Hallin RG. Blocking effects of a topical anesthetic composition containing Ketocain ${ }^{\mathrm{R}}$ on cutaneous $\mathrm{C}$ receptor responses in alert man. Acta Anesth Scand 1974;18:306-17.

${ }^{36}$ Burgess PR, Perl ER. Myelinated afferent fibers responding specifically to noxious stimulation of the skin. J Physiol (London) 1967;190:541-62.

${ }^{37}$ Collins WF, Nulsen FE, Randt CT. Relation of peripheral nerve fiber size and sensation in man. Arch Neurol 1960;3:381-5.

${ }^{38}$ Heinbecker P, Bishop GH, O'Leary J. Pain and touch fibers in peripheral nerves. Arch Neurol Psychiatry 1933;29:771-89.

${ }^{39}$ Mackenzie RA, Burke D, Skuse NF, Lethlean AK. Fibre function and perception during cutaneous nerve block. J Neurol Neurosurg Psychiatry 1975; 38:865-73.

${ }^{40}$ Adriaensen H, Gybels J, Handwerker HO, Van Hees J. Latencies of chemically evoked discharges in human cutaneous nociceptors and of the concurrent subjective sensations. Neurosci Letters 1980;20:55-9. 